\title{
Preservation areas $x$ environmental legislation in the Rio das Almas hydrographic basin, Ceres microregion (GO) between 2008/2016
}

\author{
Áreas de preservação x legislação ambiental na bacia \\ hidrográfica do rio das Almas, microrregião de Ceres
}

(GO) entre 2008/2016

Karhene Garcia Rodrigues de Sousa ${ }^{a}$

Maria Gonçalves da Silva Barbalhob

Adriana Aparecida Silva ${ }^{c}$

Cristiane Gonçalves Moraes ${ }^{\mathrm{d}}$

Josana de Castro Peixoto

${ }^{a}$ Mestre pelo Programa de Pós-graduação em Sociedade, Tecnologia e Meio Ambiente; (PPGSTMA), Centro Universitário de Anápolis, Anápolis, GO, Brasil. E-mail: karhenegarcia@hotmail.com

${ }^{b}$ Doutora em Ciências Ambientais pela Universidade Federal de Goiás e Professora Titular do Centro Universitário de Anápolis, Anápolis, GO, Brasil. E-mail: mariabarbalho2505@gmail.com

'Doutora em Geografia pela Universidade Federal de Goiás Professora titular da Universidade Estadual de Goiás (UEG), Anápolis, GO, Brasil.

E-mail: veg.adriana@gmail.com

${ }^{d}$ Mestre em Ciência e Tecnologia Ambiental pela Universidade do Vale do Itajaí e Professora Adjunta do Centro Universitário de Anápolis, Anápolis, GO, Brasil E-mail: cristianeg_moraes@yahoo.com.br

eDoutora em Biologia pela Universidade Federal de goiás e Professora titular do Centro Universitário de Anápolis e da Universidade Estadual de Goiás (UEG), Anápolis, GO, Brasil.

E-mail: josana.peixoto@gmail.com

doi:10.18472/SustDeb.v10n3.2019.24072

Received: 14/04/2019

Accepted: 06/12/2019

ARTICLE-DOSSIER 


\begin{abstract}
The aim of this research was to analyze the remaining areas of vegetation cover, with emphasis on permanent preservation areas (APPs) and legal reserve areas (RLs), in the Rio das Almas hydrographic region, Microregion of Ceres (GO). In order to analysis and mapping, it was considered two specific periods: 2008 related to the deadline established by the 2012 Forest Code to amnesty deforestation, regions nominated as consolidated rural areas, and 2016, to map and calculate APPs and RLs. The results revealed that deforestation occurred before 2008 and, therefore, possibly the vast majority of the analyzed farms fall under the amnesty provided by Law 12.651 / 2012. There was also a reduction of natural vegetation around $4.0 \%$ over the 8 -year period.
\end{abstract}

Keywords: Forest Code. Preservation Areas. Deforestation.

\title{
RESUMO
}

O objetivo desta pesquisa foi analisar as áreas remanescentes de cobertura vegetal, com destaque para áreas de preservação permanente (APPS) e de reserva legal (RLS), na região hidrográfica do rio das Almas, Microrregião de Ceres (GO). Foram consideradas duas datas para análise e mapeamento, sendo: 2008 relativo ao prazo estabelecido pelo Código Florestal de 2012 para anistiar os desmatamentos, denominadas de áreas rurais consolidadas e 2016 para o mapear e calcular as APPs e RLs. Os resultados revelaram desmatamento ocorreu antes de 2008 e, portanto, possivelmente a grande maioria das propriedades rurais analisadas se enquadram na anistia propiciada pela Lei 12.651/2012. Verificou-se ainda, uma redução da vegetação natural de pouco mais de 4,0 \% no período de 8 anos.

Palavras-Chave: Código Florestal. Áreas de Preservação. Desmatamento.

\section{INTRODUCTION}

The enactment of Law No. 12,651 of May 25, 2012, entitled Native Vegetation Protection Act (LPVN), which replaced the Forest Code of 1965, implemented some changes to the control and incentive systems for environmental preservation, art. 3rd, inc. IV refers to the insertion of the expression of the consolidated rural area that was defined as an area related to a rural property with pre-existing anthropic occupation on $07 / 22 / 2008$, with editions, benefits or agrosilvipastoral activities, admitted in the latter case to follow fallow regime.

The referred law grants several benefits to the consolidated rural areas, among which the date that deals with the approval of Decree 6,514, of July 22, 2008, which established the federal administrative proceeding to determine the infractions set forth in Law 9.605 / 1998 (Law of Environmental Crimes), which means amnesty before environmental crimes that occurred before this date (GONÇALVES, 2018).

To suspend the fines and the possibility of regularizing the agroforestry activity and infrastructure in APPs and RLs, the owners must register with the Rural Environmental Registry (CAR) which is a free and selfdeclared online service system for rural properties and possessions. for adhering to the Environmental Regularization Program (PRA) regulated by Decree 8,235 of May 5, 2014, and environmental liabilities can be resolved with the Degraded and Altered Areas Recovery Project (Prada) (Law No. 12.651, 2012).

According to the Law, landowners with up to four fiscal modules are amnesty, which do not need to compensate or reforest the RL, according to art. 67 of the Forest Code, banning new conversions of alternative land use. It is noteworthy that the Land Statute (Law 4,504 / 1964), was amended in relation to the fiscal modules (Law 6,746 / 1979), stating that the fiscal module established by the municipalities, expressed in hectares and taking into account some factors, such as predominant exploitation in the municipality and income. It is observed that in situations of non-compliance of RL there is possibility of off-property compensation, provided that it is in the same watershed (mbh) (SPAROVEK et al. 2011). 
Legal reserve areas are defined as areas located within rural properties or estates, delimited, with the function of protecting or economically using the natural resources of rural properties, auxiliary and conservation and rehabilitation of ecological processes and promoting the biodiversity conservation, as well as for the shelter and protection of fauna and flora. In the Amazon, RL must occupy $80 \%$ of rural property in forested areas and $35 \%$ in cerrado, and in other regions of the country, $20 \%$ suffer from native vegetation type (LEI N. 12.651, 2012).

Another class of preservation areas are Permanent Preservation Areas (APPs) which must be protected, whether or not covered by native vegetation. These areas have the environmental function of preserving water resources, the landscape, geological stability, biodiversity, facilitating the gene flow of fauna and flora, protecting the soil and ensuring people's well-being. Hill tops, steep slopes, restingas, mangroves, veredas, springs, watercourses, lagoons, dams, among others generate APPs. Vegetation suppression in the APP area is not allowed to build infrastructure or establish agricultural activities. However, it may be authorized in situations of social interest (Law No. 12.651, 2012).

It is worth mentioning that LPVN has established that the consolidated use in PPAs can only occur conditioned to management practices that guarantee soil and water conservation, since it is an area with important ecological functions and environmental risk (GUIDOTTI, et. al 2016).

According to studies by Dutra, Barbalho and Franco (2013), the Almas River basin in the Ceres Microregion had much of its forest cover devastated due to the expansion of the agricultural frontier, both for agricultural occupation and for the expansion of urbanization. Recently Barbalho et al. (2015) elaborated the vegetation mapping in a historical series of this area between 1975, 1985 and 2012, using landscape metrics and the results showed a high vegetation fragmentation index, with a reduction in the average fragment size. from 47.09 ha in 1975 to 15.5 ha in 2012, and an increase in border density from 62.08 ha in 1975 to 132.78 ha in 2012. These data demonstrate a high degree of vegetation degradation, relative to the low connectivity between the remaining forest formations, which can be correlated to the expansion of the agricultural frontier, which was characterized by intensive deforestation.

The purpose of this research was to analyze the vegetation cover, the permanent preservation areas and legal reserve in the hydrographic region of Rio das Almas - Ceres microregion (GO), in two dates: 2008 deadline established by the 2012 Forest Code to amnesty deforestation , known as consolidated rural areas and, 2016 where the vegetation still occurring in the research area is verified and quantify the permanent preservation and legal reserve areas in 15 rural properties.

\section{METHODOLOGY}

Located in the central portion of the state of Goiás, the Mato Grosso de Goiás region had large forested areas that lined valleys, slopes and high tops, with an area of approximately $20,000 \mathrm{~km} 2$. These forested areas were considered as first class forests associated with the best soils that occurred in the valley of the Rio das Almas and its tributaries, where crops and the best wintering are practiced. And second-class forests that appeared near drainage headwaters, high in the plateaus or in the border areas between first-class and savannah forests, commonly used for grazing, since second-tier forest soil was rapidly depleted when cultivated (FAISSOL, 1952).

Mato Grosso de Goiás also encompassed the local denominations of Mata de São Patrício and Santa Luiza once these forests were connected. Currently there is a significant decrease in vegetation cover (BARBALHO et al. 2017). This reduction in vegetation was observed throughout the Cerrado Biome (KLINK; MORREIRA, 2002; MACHADO et. Al. 2004; SANO et al., 2006; STRASSBURG et al, 2017).

The Rio das Almas hydrographic region - S. Patrício river / Peixe river - Ceres microregion (GO), is between the geographic coordinates of South Latitude from 14 59 '11 "to 15 16' 27" and Longitude 
West 49 11 ' 57 ', with an area of 65,677.44 hectares. It covers part of the areas of the municipalities of Nova Gloria $(14,808.04$ ha), Santa Isabel $(32,819.61$ ha) and Goianésia (18,049.81 ha) (Figure 1).

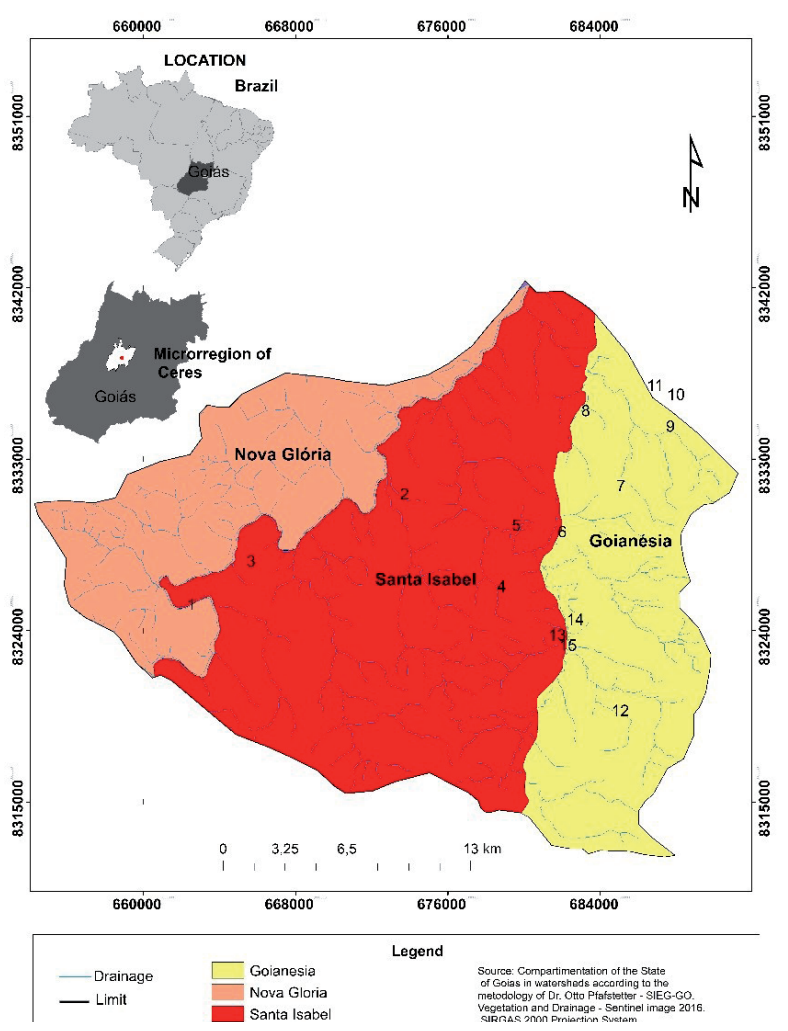

Figure 1 | Study area location map Source: Elaborated by the author (2018).

The human occupation of the municipalities that make up the study area is higher in urban areas representing just over $89.58 \%$, while the rural population accounts for $10.41 \%$. The municipality of Goianésia has the largest number of inhabitants (over 20,000 inhabitants) with 59,549, followed by Santa Isabel with 3,686 and Nova América 2,259 inhabitants. The economy is based on agriculture, mainly extensive cattle raising and crops such as soybeans, corn and sugar cane. The urban economy, on the other hand, relies on commercial and service activities to meet local demands (IBM, 2015).

The predominant climate is AW type by the Koppen climate classification, with two seasons: one dry (winter) and one wet (summer) (CARDOSO, 2014). Geology predominates in areas with more recent surface formations represented by Ferruginous debris-lateritic coverings which comprise alluvial or colluvial sediments consisting of oligomitic conglomerates with quartzite pebbles and autochthonous laterites with rust-bearing carapaces. And the Alluvial Deposits that are associated with the drainage network and are not extensive and comprise accumulations of sand, gravel and lenses of silty-clay and peat material (LACERDA FILHO, et al. 2008).

In geomorphology it is located in the Central Goiano Plateau which reflects relief features resulting from the exhumation of the bent structures resulting from various tectonic cycles. Reliefs with up to $12 \%$ (93\% of the area) predominate. Therefore, in topographic order restrictions for mechanization. The wavy mountainous reliefs represent only $7 \%$ of the area, being restricted the areas of the mountains. Reliefs with up to $12 \%$ (93\% of the area) predominate. Therefore, no topographic order restrictions for mechanization. The wavy mountainous reliefs represent only $7 \%$ of the area, being restricted the areas of the mountains.

The soil classes that occur in the basin area are the Oxisols (67.90\%), Nitosols (27.90\%) and Cambisols (EMBRAPA, 2013). The characteristics of these soils are described below: 
Oxisols comprise soils made of mineral material, with latosolic B horizon just below any of the types of superficial diagnostic horizon, except for histic $\mathrm{H}$. They have an advanced stage of weathering. They are virtually devoid of primary minerals and have low cation exchange and base saturation capabilities. They range from heavily drained to well drained. They are usually very deep, usually acidic, dystrophic or alic. They occur in flat to smooth wavy relief. In the research area they represent $45.83 \%$ of the area and the following suborders occur:

Cambisols (C) are soils consisting of mineral material with incipient B horizon underlying any type of surface horizon. They are strong to imperfectly drained, ranging from shallow to deep, brownish or yellowish to dark red, and from high to low base saturation and chemical activity in the colloidal fraction. In the area there is the suborder of Cambisol Dystrophic Habits (CXbd), medium to gravelly and eutrophic (CXbe) and (CXbef), gravelly and stony, medium to clayey texture, wavy and strong wavy relief.

Nitosols $(\mathrm{N})$ consist of mineral material with a nitric $\mathrm{B}$ horizon below horizon $\mathrm{A}$. The nitric horizon has low activity or alitic character. In the area occurs the suborder of Red Nitosols (NV) in wavy relief.

\subsection{METHODOLOGICAL PROCEDURES}

Drainage network mapping - From the Sentinel image, the drainage network was digitalized in the SPRING / 5.2.7 Program in the approximate scale of 1 / 25,000.

Demarcation of Permanent Preservation Areas (APPs) - It was carried out based on the Forest Code, Federal Law 12,651 of 2012 which established the preservation bands according to the width of the watercourse (less than 10 meters; the range is 30 meters; from 10 to 50 meters the range is 50 meters, from 50 to 200 meters the range is 100 meters, from 200 to 600 meters the range is 200 meters and the largest from $600 \mathrm{~m}$ the range is 500 meters. In this step we used the buffer tool in ArcGis 10.1 which creates a polygon around the points, lines or polygons that are representing the drainage elements with value informed about the widths of the APPs.

To delimit the slope APPs, the slope gradient matrix map was prepared in ArcGIS 10.1 using the "Slope" tool. Subsequently, the slope map was reclassified in order to delimit only APPs greater than 45․

For the hilltops the 2012 Forest Code established a minimum height of $100 \mathrm{~m}$ and an average slope of 25․ APPS shall cover the set of hills or peaks whose ridges are less than 500 meters apart, delimited from the level curve at two thirds of the height of the base of the lowest set hill or mountain. To delimit the hilltops, the methodology of Hott et al (2004) was used.

Natural Vegetation Mapping - Landsat TM 5 - RGB / 5432008 and Sentinel 2016 satellite images were used to identify and quantify the vegetation of the area. In these images, classification through segmentation based on the region growth algorithm was used, which labels each "pixel" as a distinct region until every image is segmented (BLASCHKE AND KUX, 2005; BECKER, et al., 2012; BLASCKE et al., 2014). Subsequently, the vegetation areas were classified and the vegetation map was prepared.

Delimitation of rural properties - 15 properties were selected in the watershed area under study to calculate the areas of RLS and APPs. The criterion for the selection of the property was to be fully implemented in the basin area and to be included in the INCRA database, available in the "Shape file" file format. These data were entered in the SPRING 5.2.7 database. The properties were classified according to the Law 8,629 / 1993 that takes into account the fiscal module, which varies according to each municipality, as follows: Minifundia - area is less than 01 fiscal module; Small Property - area between 01 and 04 fiscal modules; Mean Property, in area greater than 04 and up to 15 tax modules and Large Property, in area greater than 15 tax modules. 
With the data obtained in the previous stages, the areas covered by vegetation in 2008, 2016 and APPs and RLs in rural properties were calculated, enabling the identification of those that are or are not in line with the Forest Code.

\section{RESULTS}

Data from the natural vegetation areas of the Rio das Almas Hydrographic Region, Microregion of Ceres (GO), based on the mapping for 2008 and 2016, which was carried out on an approximate 1: 50,000 scale, was verified. whereas natural vegetation occupied $21.66 \%$ in 2008 and in 2016 covered $17.55 \%$ of the study area, with an 8-year reduction of just over $4 \%$ of natural vegetation. With the vegetation mapping of 2016, Legal Reserve Areas (RLs), Permanent Preservation Areas (APPs) were delimited and calculated, as well as identified in the 15 rural properties analyzed areas that are not in line with the Forest Code.

Among the 15 rural properties selected in this study, according to the criteria adopted by INCRA for property size, 66\% are classified as Large (with areas larger than 15 fiscal modules), 20\% Small (with areas between 1 and 4 fiscal modules ha) and 13\% as Minifundia (1 fiscal module) (Figure 1 and Table 1).

Table 1 | Area of rural properties, of natural vegetation (2008 and 2016) and Legal Reserve - Rio das Almas hydrographic region - Ceres Microregion (GO).

\begin{tabular}{|c|c|c|c|c|c|c|c|}
\hline \multirow{2}{*}{ Property } & \multirow{2}{*}{$\begin{array}{l}\text { Property } \\
\text { area (ha) }\end{array}$} & \multirow{2}{*}{$\begin{array}{l}\text { Fiscal Module } \\
\text { (ha) }\end{array}$} & \multirow{2}{*}{$\begin{array}{l}\text { Classificação } \\
\text { INCRA }\end{array}$} & \multicolumn{2}{|c|}{$\begin{array}{l}\text { Natural vegetation area } \\
\text { (ha) }\end{array}$} & \multirow{2}{*}{$R L(h a)$} & \multirow{2}{*}{$\begin{array}{l}\text { Natural vegetation } \\
\text { area of } 2016 \text { in rela } \\
\text { tion to } R L(\%)\end{array}$} \\
\hline & & & & 2008 & 2016 & & \\
\hline 1 & 337,91 & 16,9 & Big & 25,46 & 20,67 & 67,58 & 30,59 \\
\hline 2 & $4.296,78$ & 214,84 & Big & 447,81 & 465,73 & 859,36 & 54,19 \\
\hline 3 & $1.019,70$ & 50,99 & Big & 141,9 & 110,53 & 203,94 & 54,2 \\
\hline 4 & $1.909,70$ & 95,47 & Big & 155,24 & 54,33 & 381,87 & 14,23 \\
\hline 5 & $2.597,31$ & 129,87 & Big & 594,43 & 566,02 & 519,46 & 108,96 \\
\hline 6 & 619,47 & 30,97 & Big & 69,43 & 86,54 & 123,89 & 69,85 \\
\hline 7 & 765,99 & 38,3 & Big & 204,23 & 212,13 & 153,2 & 138,47 \\
\hline 8 & $2.260,17$ & 113,01 & Big & 156,8 & 111,97 & 452,03 & 24,77 \\
\hline 9 & 104,94 & 5,25 & Small & 80,11 & 94,07 & 20,99 & 448,17 \\
\hline 10 & 313,11 & 15,66 & Big & 33,77 & 44,38 & 62,62 & 70,87 \\
\hline 11 & 487,35 & 24,37 & Big & 55,79 & 29,87 & 97,47 & 30,65 \\
\hline 12 & 74,52 & 3,72 & Small & 55,91 & 8,79 & 14,9 & 58,99 \\
\hline 13 & 36,81 & 1,8 & Small & 1,47 & 1,65 & 7,36 & 22,42 \\
\hline 14 & 11,52 & 0,58 & Minifundium & 3,35 & 3,03 & 2,3 & 131,74 \\
\hline 15 & 23,22 & 1,16 & Minifundium & 5,04 & 3,66 & 4,64 & 78,88 \\
\hline Total & $14.858,19$ & 742,91 & & $2.030,74$ & $1.813,37$ & $2.971,61$ & $1.336,98$ \\
\hline
\end{tabular}


Still according to the data in Table 1, it can be verified that the properties identified with numbers 12,13, 14 and 15 have an area smaller than 04 fiscal modules, ie smallholdings and, therefore, according to art. 67 of the Forest Code, do not need to compensate or reforest the RLs, barring new conversions of alternative land use. The properties listed as 2, 9, 10 and 13 showed an increase in the area of RLs during the study period, which may be correlated to the recovery of areas due to the Forest Code. Already the properties number 5, 7, 9 and 14 have larger area of RLs than established by the Legislation. The properties number $1.4,8.11$ and 13 have respectively $30 \%, 14 \%, 24 \%$ and $22 \%$ of the area destined for RL with natural vegetation; Properties 2, 3, 12 have slightly more than $50 \%$ of the area intended for natural vegetation RLs and properties 6,10 , and 15 have $70 \%$ of the area that should be intended for vegetation RLs.

Table 2 | shows data on the areas of water APPs delimited in the 15 rural properties corresponding to an area of 980.66 ha according to what was established by the Forest Code. Of this total only 449.60 ha have vegetation cover, or $46 \%$. The other $54 \%$ are in disagreement with the Forest Code and are concentrated in large rural properties with 491.76 ha $(92.59 \%)$ of APPs without vegetation. The medium and small properties represent just over $7 \%$ of the area with deficit of APPs.

\begin{tabular}{|c|c|c|c|c|c|c|}
\hline \multirow{3}{*}{ Property } & \multicolumn{4}{|c|}{ Area of Hidraulic APPs - Forest Code, Federal Law 12.651 of 2012(m) } & \multicolumn{2}{|c|}{$\begin{array}{c}\text { Area of APPs without natural } \\
\text { coverage of } 2016\end{array}$} \\
\hline & \multicolumn{6}{|c|}{ Area } \\
\hline & 30 & 50 & 100 & Total & Total & (\%) \\
\hline 1 & 17,58 & 1,53 & 39,82 & 58,93 & 40,96 & 69,5 \\
\hline 2 & 205,46 & 73,7 & 12,08 & 300,24 & 161,99 & 53,95 \\
\hline 3 & 29,03 & 0,76 & 79,62 & 109,41 & 71,41 & 65,26 \\
\hline 4 & 84,72 & 7,78 & & 92,5 & 76,54 & 82,74 \\
\hline 5 & 93,79 & 78,59 & & 172,38 & 51,04 & 29,6 \\
\hline 6 & 11,96 & 28,33 & & 40,29 & 14,15 & 35,12 \\
\hline 7 & 29,26 & 0,75 & & 30,01 & 7,44 & 24,79 \\
\hline 8 & 92,43 & 4,58 & & 97,01 & 60,52 & 62,38 \\
\hline 9 & 12,56 & & & 12,56 & 2,05 & 16,32 \\
\hline 10 & 10,65 & & & 10,65 & 1,56 & 14,64 \\
\hline 11 & 11,37 & 0,75 & & 12,12 & 6,15 & 50,74 \\
\hline 12 & 26,41 & 1,55 & & 21,96 & 26,62 & 95,2 \\
\hline 13 & 2,02 & & & 2,02 & 1,56 & 77,22 \\
\hline 14 & 1,93 & 7,67 & & 9,6 & 6,78 & 70,62 \\
\hline 15 & 4,98 & & & 4,98 & 2,29 & 45,98 \\
\hline Total & 634,15 & 205,99 & 140,52 & 980,66 & 531,06 & 54,15 \\
\hline
\end{tabular}

Source: Elaborated by the author (2018). 
It is worth mentioning that for rural areas with consolidated use, the restoration ranges of APPs according to the Forest Code should be 5 meters from the edge of the bed channel, in rural properties with up to 1 fiscal module. On properties between 1 and 2 fiscal modules the restoration should be 8 meters, while on properties between 2 and 4 fiscal modules should be 15 meters. For the higher modules recomposition should be from 20 to 100 meters.

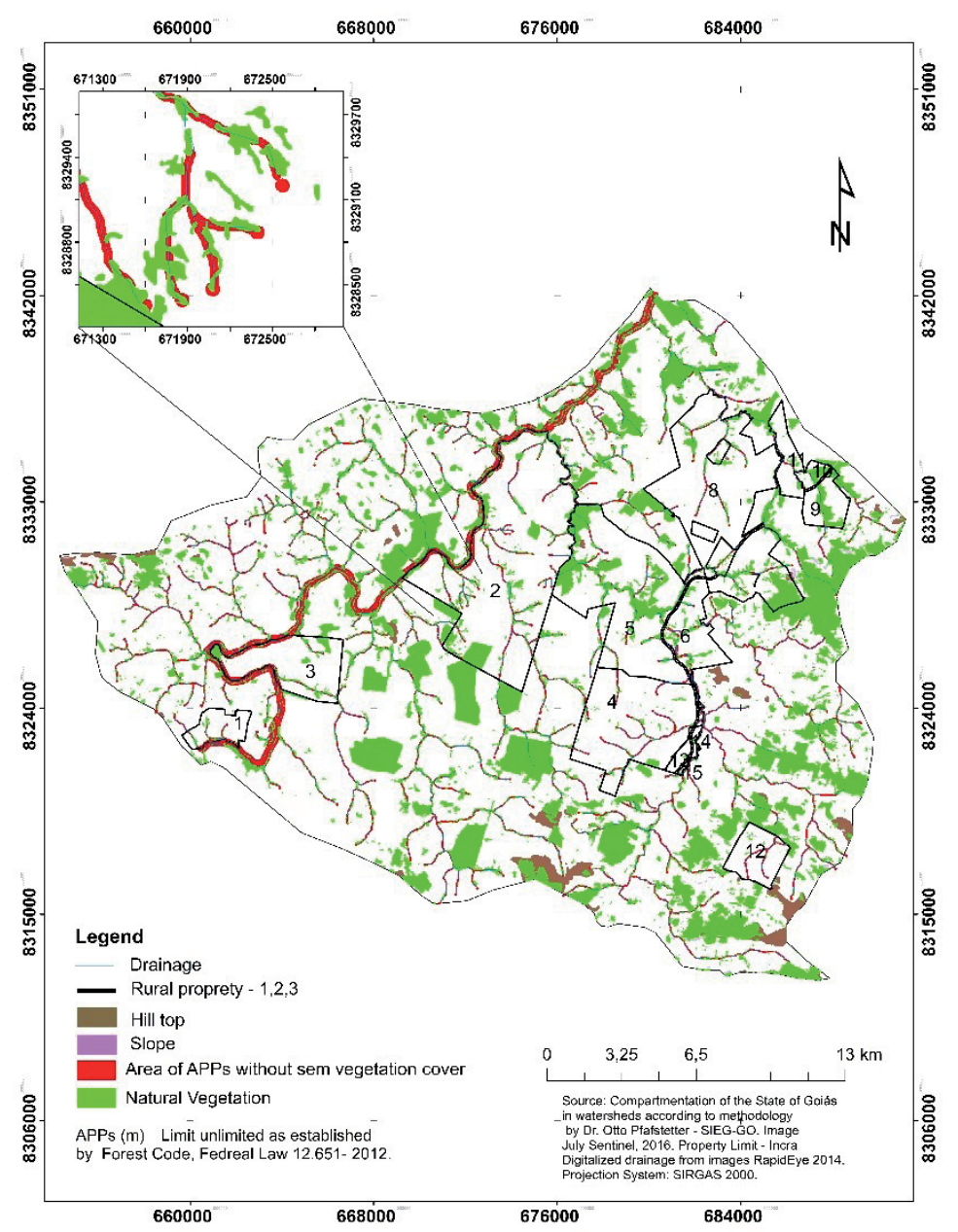

Figure 2 | Vegetation Map (2016) with APPs and boundary of properties of the Rio das Almas Hydrographic Region - Ceres Microregion (GO). Souce: Elaborated by the author (2018).

\section{DISCUSSION}

In the Rio das Almas Hydrographic Region, study area, there are 4 properties with natural vegetation surpluses and 11 with liabilities (deficits) to the Legal Reserve (RLs) and Permanent Protection Areas (APPs) requirements according to the legislation in force. Similar results were found Azevedo, et al. (2015) who analyzed 9,113 rural properties in the Amazon portion of Mato Grosso to verify the degree of non-compliance of producers with the Forest Code. They found that almost $70 \%$ of farms do not comply with the Forest Code.

In studies by Soares et al. (2011) in the São Bartolomeu river basin, Viçosa, MG, the results indicated that, of the 292 properties evaluated, only 41 (14\%) have vegetation cover above $20 \%$, being able to comply with environmental legislation in the state. refers to the legal reserve. 
It is important to mention that properties that have RL surpluses will be able to sell them in Environmental Reserve Quotas (CREA) among producers that need to recover the RL of their property, as long as they are limited in the same biome (art. 48, BRAZIL, 2012). However, only owners with more than four modules may enter into environmental easement contracts. Environmental easement deals with the voluntary waiver of the rural owner to the right to use, exploit or suppress the natural resources existing in his property.

In the 2008 and 2016 temporal analysis of the Vegetation Coverage in the Rio das Almas Hydrographic Region - Foz Rio S. Patrício / Rio do Peixe - Ceres Microregion (GO) it was found that deforestation occurred before 2008 and, therefore, possibly the great Most of the rural properties analyzed fall within the amnesty provided by Law 12.651 / 2012. Silva et al. (2014); Sparovek et al. (2011, 2012) showed that the mechanisms of this law reduced the liabilities of APPs and RLs in all biomes and regions of Brazil. And 41 million hectares exempt from the need for restoration, of which 36.5 million RLs and 4.5 million APPs (GUIDOTTI et al., 2017).

They also stressed that the environmental services that could be produced by 4.5 million hectares of PPAs cannot be given up and that these areas should be restored especially for the protection of water resources and the multiple uses of their waters. In a context of climate change the recovery of these areas should be prioritized and encouraged.

Brancolin et al. (2016) consider that the regularization of activities in permanent preservation areas without the need for full recovery of native vegetation may compromise soil and water source protection, biodiversity conservation and agricultural production. This reduction in the width of the strips to be reclaimed along the 5 to 100 meter water APPs, depending on the size of the property, in consolidated rural areas is one of the setbacks of the Native Vegetation Protection Act (LPVN). In the case of RLs assess that compensation of the elimination of native vegetation in lands of the same biome, located in a watershed that may be even in another State, disregards the environmental criteria linked to the function of RLs.

The biomes that presented the largest relative amnesty of APPs were Cerrado, Caatinga and Pampa. In terms of total area, the forgiveness of 390,000 ha of water APPs in the Amazon exceeds the amnesty amount in the Pampa (GUIDOTTI et al.2017). Nunes et al. (2014) and Silva et al. (2018) highlighted the loss with loss of areas in the Amazon, especially riparian areas, consolidated for economic use by the current forest law.

\section{FINAL CONSIDERATIONS}

The adoption of the methodology based on a Geographic Information System (GIS) proved to be efficient, since it allowed to generate information about APPs and RLs in the area of the Rio das Almas Hydrographic Region.

Satellite image analysis revealed that deforestation occurred before July 2008. And that during the period 2008 - 2016 there were no significant changes in vegetation in the 15 farms. They also made it possible to identify and quantify unduly occupied areas, as well as consolidated use.

The use of satellite imagery mainly as regards coverage patterns is critical as they can subsidize surveillance to prevent new protected areas from being occupied and degraded.

Finally, it is hoped that this research may contribute to other studies aimed at providing information to environmental agencies, as well as to guide and stimulate the active participation of rural landowners for the restoration and preservation of PPAs and RLs. 


\section{ACKNOWLEDGEMENTS}

With the support of CAPES (Higher Education Personnel Improvement Coordination) and PROCAD (National Academic Cooperation Program) between UNESP, UnB and UniEVANGÉLICA from the Project entitled "New Frontiers in the West: Relationship between Society and Nature in the Microregion of Ceres in Goiás (1940-2013)"- Case No. 2980/2014.

\section{REFERENCES}

AZEVEDO, A. A.; STABILE, M. C. C.; REIS, T. N. P. Commodity production in Brazil: combining zero deforestation and zero illegality. Elementa: Science of the Anthropocene, v. 3, n. 1, p. 12, 2015.

BARBALHO, M. G. da S. Avaliar os efeitos do desmatamento nos solos e nos recursos hídricos na bacia do Rio das Almas, microrregião de Ceres (GO). Relatório de Pós-Doutorado - Procad/Capes, Universidade de Brasília, 2017.

BARBALHO, M. G. da S.; SILVA, S. D.; DELLA GIUSTINA, C. C. Avaliação temporal do perfil da vegetação da microrregião de Ceres através do uso de métricas de paisagem. Boletim Goiano de Geografia, 2015.

BECKER, C.; OSTERMAN, J.; PAHL, M. Automatic quality assentamento of gis data base an object coherence. In: Procedings of the 4th Geobia. Rio de Janeiro [s/n], 2012.

BLASCHKE, T. et al. Geographic Object-Based Image Analysis - Towards a new paradigman. ISPRS Journal of Photogrammetry and Remote Sensing, v. 87, p.180-1091, 2014.

BLASCHKE, T.; KUX, H. Sensoriamento Remoto e SIG Avançados: novos sistemas sensores, métodos inovadores. São Paulo: Oficina de Textos, 2005.

BRANCOLION, P. H. S. et al. Análise crítica da Lei de Proteção da Vegetação Nativa (2012), que substituiu o antigo Código Florestal: atualizações e ações em curso. Natureza e Conservação, v. 14, p. e1-e16, 2016.

BRASIL. Lei n. 12.651, de 25 de maio de 2012. Institui o Novo Código Florestal Brasileiro. Disponível em: <http:// www.planalto.gov.br/ccivil_03/_ato2011-2014/2012/lei//12651.htm>. Acesso em: 12 jan. 2018.

CARDOSO, M. R. D. Classificação climática de Köppen-Geiger para o estado de Goiás e o Distrito Federal. ACTA Geográfica, Boa Vista, v. 8, n. 16, p. 40-55, jan./mar. 2014.

COORDENAÇÃO DE APERFEIÇOAMENTO DE PESSOAL DE NÍVEL SUPERIOR. Relatório de avaliação trienal da área de ciências ambientais. Brasília: Capes, 2013.

EMPRESA BRASILEIRA DE PESQUISA AGROPECUÁRIA. Centro Nacional de Pesquisa de Solo. Sistema Brasileiro de Classificação de Solos: 3. ed. Rio de Janeiro: Embrapa Solos, 2013.

FAISSOL, S. O “Matogrosso de Goiás”. Instituto Brasileiro de Geografia e Estatística (IBGE). Conselho Nacional de Geografia, Rio de Janeiro, 1952.

FERREIRA, L. C. G.; DEUS, J. B. O uso do território e as redes na microrregião de Ceres (GO): o caso das agroindústrias sucroalcooleiras. B. Goiano de Geogr. Goiânia, v. 30, n. 2, p. 67-80, jul./dez. 2010.

GONÇALVES, J. S. A evolução da proteção da Reserva Florestal Legal no Brasil e a segurança jurídica. Revista Direito Ambiental e Sociedade, v. 8, n. 1. p. 237-264, 2018.

GUIDOTTI, V. et al. Código Florestal: contribuições para a regulamentação dos programas de regularização ambiental (PRA). Sustentabilidade em Debate, set. de 2016. 
GUIDOTTI. V. et al. Números detalhados do novo Código Florestal e suas implicações para os PRAs. Sustentabilidade em Debate, n. 5, 2017.

HOTT, M. C.; GUIMARÃES, M.; MIRANDA, E. E. Método para a determinação automática de Áreas de Preservação Permanente em topos de morros para o estado de São Paulo, com base em geoprocessamento. Campinas: Embrapa Monitoramento por Satélite, 2004.

INSTITUTO BRASILEIRO DE GEOGRAFIA E ESTATÍSTICA. Mapas de Geologia, Geomorfologia e Solos na escala 1:250.000, Rio de Janeiro, 2013.

INSTITUTO MAURO BORGES. Estatísticas Georreferenciadas - BDE-Goiás. Disponível em: <http://www.sieg. go.gov.br>

KLINK, C. A.; MACHADO, R. B. Conservation of the Brazilian Cerrado. Conservation Biology, v. 19, n. 3, p. 707-713, 2005.

MACHADO, R. B. et al. Estimativas de perda de área do Cerrado brasileiro. Relatório Técnico. Conservação Internacional, Brasília, DF, 2008.

NUNES, S. S. et al. A 22 year assessment of deforestation and restoration in riparian forests in the eastern Brazilian Amazon. Environmental Conservation, Lancaster, v. 42, n. 3, p. 193-203, 2014.

RIBEIRO, C. A. A. S. et al. Valoração das Áreas de Preservação Permanente na Bacia do Rio Alegre-ES. Revista Floresta e Ambiente, v. 17, n. 1, p. 63-72, 2010.

SANO, E. E. et al. Mapeamento semidetalhado do uso da terra do bioma Cerrado. Pesq. Agropec. Bras. Jan 2008, v. 43, n. 1, p.153-156.

SILVA, S. D.; BARBALHO, M. G. da S.; FRANCO, J. L. de A. Expansão sucroalcooleira e a devastação ambiental nas matas do São Patrício, microrregião de Ceres, GO. Histórias, Histórias. Brasília, v. 1 n. 1, 2013.

SILVA, J. S. da; RANIERI, V. E. L. O mecanismo de compensação de Reserva Legal e suas implicações econômicas e ambientais. Ambiente \& Sociedade, v. 17, n. 1, p. 115-132, 2014.

SILVA, N. M. et al. The negative influences of the new brazilian forest code on the Conservation of riparian forests. European Journal of Ecology, Varsóvia, v. 3, n. 2, p. 116-122, 2018.

SOARES, V. P. S. et al. Mapeamento das Áreas de Preservação Permanente e dos fragmentos 555 florestais naturais como subsídio à averbação de Reserva Legal em imóveis rurais. Cerne, Lavras, v. 17, n. 4, p. 555-561, out./dez. 2011.

SOARES FILHO, B. et al. Cracking Brazil's Forest Code. Science, v. 344, n. 6182, p. 363-364, Apr. 25, 2014. Disponível em: <https://www.researchgate.net/publication/310599766_Cracking_Brazil's_Forest_Code>.

SPAROVEK, G. et al. A revisão do Código Florestal brasileiro. Novos Estudos - Cebrap, v. 89, n. 89, p. 111-135, 2011.

SPAROVEK, G. et al. The revision of the brazilian forest act: increased deforestation or a historic step towards balancing agricultural development and nature conservation? Environmental Science and Policy, v. 16, p. 65-72, 2012.

STRASSBURG, B. N. et al. Moment of truth for the Cerrado Hotspot. Nature Ecology e Evolution, v. 1, n. 99, 2017. 